\title{
Comparison of in situ hybridisation and polymerase chain reaction in the diagnosis of $B$ cell lymphoma
}

\author{
A M McNicol, M A Farquharson, F D Lee, A K Foulis
}

\begin{abstract}
Aim-To compare the sensitivity of the detection of immunoglobulin light chain messenger RNA (mRNA) restriction by in situ hybridisation (ISH) and clonal immunoglobulin heavy chain gene rearrangements by polymerase chain reaction (PCR) in the diagnosis of $B$ cell lymphoma.

Methods-Analyses were applied to formalin fixed, paraffin wax embedded, routine diagnostic specimens from cases with a provisional diagnosis of reactive lymph node $(n=23)$, B cell lymphoma $(n=21)$, and $T$ cell lymphoma $(n=4)$. Nonisotopic ISH for kappa and lambda immunoglobulin light chain mRNA was performed using both fluorescein and digoxigenin labelled oligodeoxynucleotide probe cocktails. PCR was carried out on DNA extracted from sections using primers to framework 3 (Fr3) of the V segments and to conserved sequences from the $J$ regions of the immunoglobulin heavy chain genes.

Results-All reactive lymph nodes showed a polyclonal pattern of light chain $\mathrm{mRNA}$ by ISH, although one showed an excess of kappa positive cells. Nineteen of $21(90 \%)$ cases of $B$ cell lymphoma showed light chain restriction, and a further case showed a vast excess of kappa positive cells. By PCR, 20 of 23 reactive nodes (87\%) showed a polyclonal pattern. In 13 of 21 B cell lymphomas $(62 \%)$ a clonal band was detected.

Conclusion-In the diagnosis of $B$ cell lymphoma in routinely processed diagnostic material ISH for light chain mRNA was more sensitive $(90 \%)$ than PCR for heavy chain gene rearrangement using Fr3 and $J$ region primers $(62 \%)$.

(F Clin Pathol 1998;51:229-233)
\end{abstract}

University

Department of

Pathology, Glasgow

Royal Infirmary

University NHS Trust,

Castle Street, Glasgow

G4 OSF, Scotland, UK

A M McNicol

M A Farquharson

F D Lee

A K Foulis

Correspondence to:

Dr McNicol.

Accepted for publication 13 January 1998 lins. Several reports have indicated a higher sensitivity for ISH than for immunocytochemistry. ${ }^{1-4}$

Clonality may also be demonstrated by molecular genetic analysis of immunoglobulin heavy chain gene rearrangements, which initially used Southern blot analysis of fresh tissue. ${ }^{5}$ However, the polymerase chain reaction (PCR) and sections of fixed tissues can now be used..$^{6-8}$ Although less sensitive than Southern blot analysis, it has also been reported to be more sensitive than immunohistochemical detection of kappa and lambda light chain restriction, ${ }^{9}{ }^{10}$ and can be performed on paraffin wax embedded diagnostic material.

To date, there has been no reported study directly comparing ISH and PCR in the detection of clonality on the same cases. The aim of our study, therefore, was to perform such a comparison in a series of paraffin wax embedded lymph nodes submitted for diagnostic investigation to our surgical pathology service.

\section{Methods}

CASES

Lymph nodes were fixed in neutral buffered formalin and processed to paraffin wax. Based on morphological and immunohistochemical characterisation, a provisional diagnosis was made of reactive lymph node $(n=23), B$ cell lymphoma $(n=21)$, and $T$ cell lymphoma $(n=4)$. Cases in each group were selected on a random retrospective basis. The $\mathrm{B}$ cell tumours were diagnosed in the REAL classification as follicular lymphoma $(\mathrm{n}=7)$, large B cell lymphoma $(n=9)$, lymphoplasmacytic lymphoma $(\mathrm{n}=1)$, and lymphocytic lymphoma $(\mathrm{n}=4)$. Human tonsil was included as a technical control.

IN SITU HYBRIDISATION

The ISH technique was based on previous publications. ${ }^{2}$ Sections ( $4 \mu \mathrm{m}$ thick) were cut on to silane coated slides. All solutions used before hybridisation were diethylpyrocarbonate (DEPC) treated. The sections were dewaxed to water. They were incubated in $0.2 \mathrm{M} \mathrm{HCl}$ for 20 minutes, washed in water, then immersed in $2 \times$ SSC $(1 \times$ SSC $=0.15 \mathrm{M}$ sodium chloride, $0.015 \mathrm{M}$ sodium citrate) at $70^{\circ} \mathrm{C}$ for 10 minutes before digestion with proteinase $\mathrm{K}$ (Sigma, Poole, Dorset, UK) at $10 \mu \mathrm{g} / \mathrm{ml}$ for one hour at $37^{\circ} \mathrm{C}$. This reaction was stopped with $0.2 \%$ glycine before washing in water and postfixing in freshly prepared $0.4 \%$ paraformaldehyde for 20 minutes at $4^{\circ} \mathrm{C}$. The sections were washed again in water, then rinsed in methylated spirits, and allowed to air dry. 

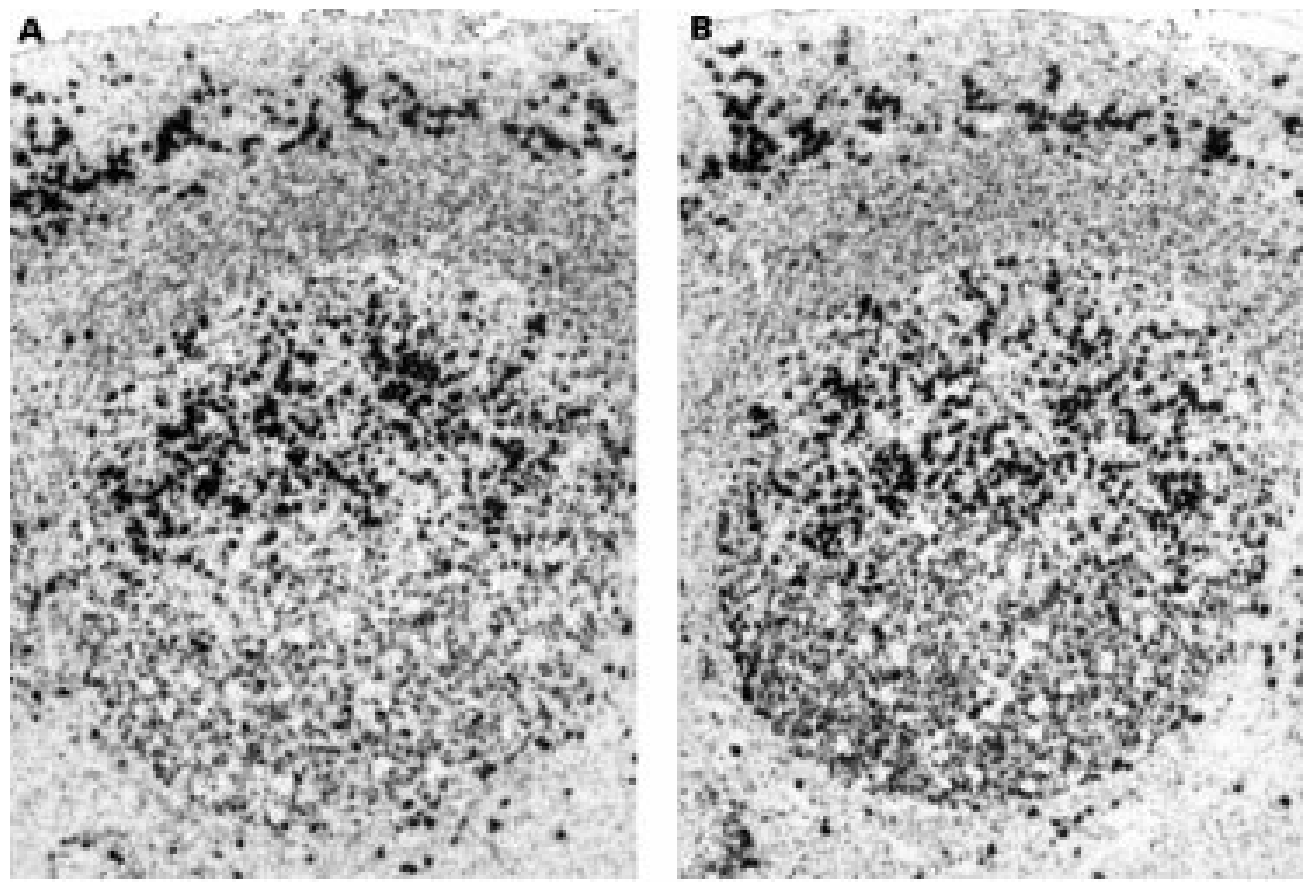

Figure 1 Reactive lymph node. ISH for kappa (A) and lambda (B) light chain mRNA shows a polyclonal pattern.

PROBES

Two different sources of probes were used in this study: fluorescein (FITC) labelled oligonucleotide cocktails to kappa and lambda light chain mRNA (Dako, High Wycombe, Bucks, UK) were used initially. Detection was achieved using an alkaline phosphatase labelled anti-FITC antibody (Dako). When production of these probes ceased, we changed to digoxigenin labelled cocktails ( $R$ \& $D$, Abingdon, Oxfordshire, UK), detection being attained with an alkaline phosphatase conjugated antibody to digoxigenin (Boehringer, Lewes, East Sussex, UK). Both sets of probes were subjected to the same pre- and posthybridisation conditions.

POST-HYBRIDISATION

Following overnight hybridisation at $37^{\circ} \mathrm{C}$, the coverslips were removed in $2 \times \mathrm{SSC}$ and the

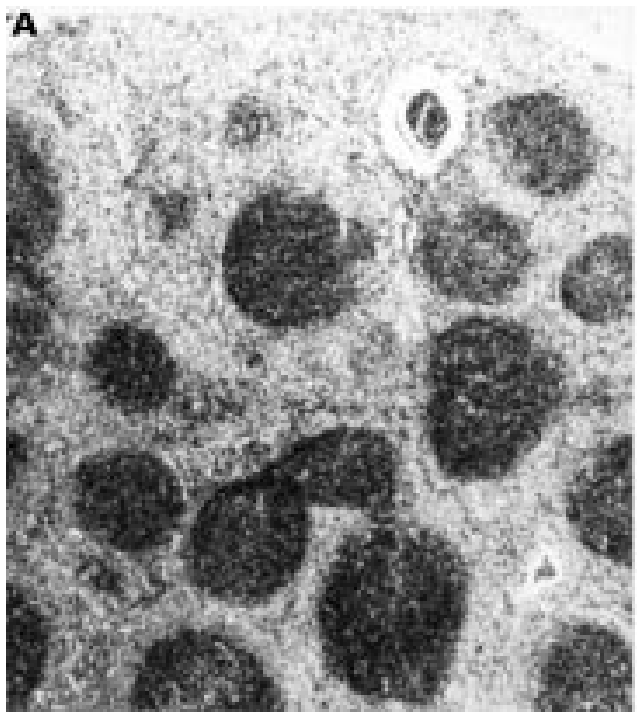

sections washed for five minutes in fresh $2 \times$ SSC, then in Tris buffered saline (TBS), $0.1 \%$ Triton $\mathrm{X}$ for 10 minutes. This was followed by two washes in TBS before incubation with the relevant antibody for 30 minutes. The antibody was removed with a TBS wash. The products were visualised with a standard alkaline phosphatase detection system using nitroblue tetrazolium (NBT)/5-bromo-4-chloro-3-indolyl phosphate (BCIP) as substrate, the slides being incubated in dye overnight. The slides were lightly counterstained with haematoxylin and water mounted using Glycergel (Dako).

POLYMERASE CHAIN REACTION

A $10 \mu \mathrm{m}$ section was cut from each block, a fresh knife being used for each new block. The sections were dewaxed using $1 \mathrm{ml}$ xylene, vortexed, then centrifuged at $13000 \times \mathrm{g}$ for five minutes. The supernatant was carefully dis-

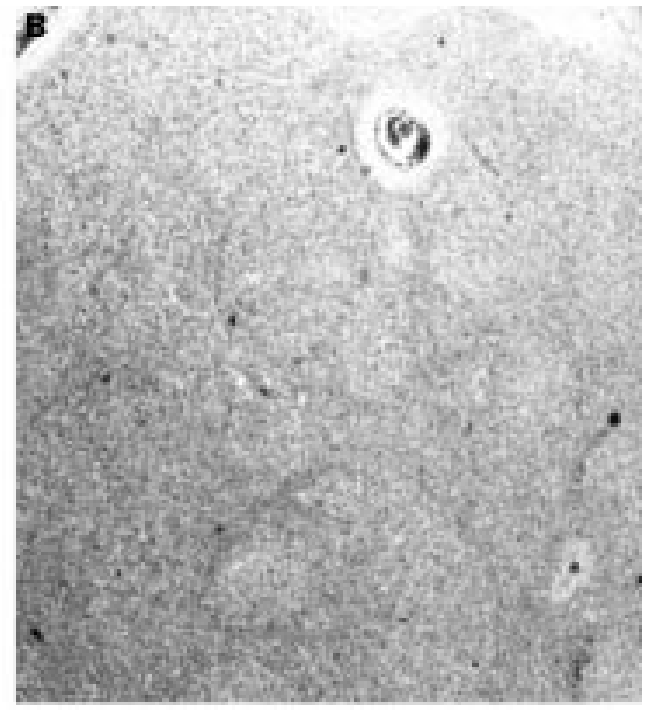

Figure 2 Follicular lymphoma. ISH for kappa (A) and lambda (B) light chain $m R N A$ shows kappa restriction. 

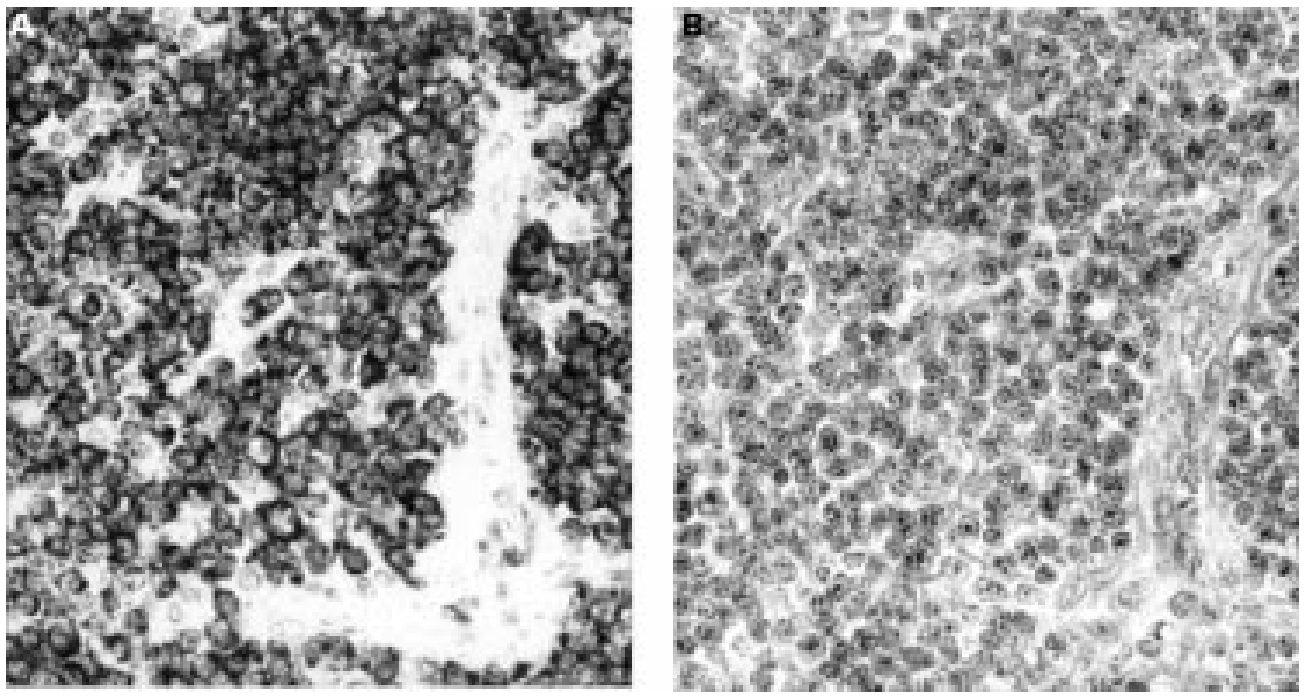

Figure 3 Lymphocytic lymphoma. ISH for kappa (A) and lambda (B) light chain $m R N A$ shows kappa restriction.

carded and a fresh $1 \mathrm{ml}$ aliquot of xylene was added. This procedure was repeated twice with $1 \mathrm{ml}$ absolute alcohol. The pellet was dried using a vacuum desiccator. An aliquot of $100 \mu \mathrm{l}$ of $500 \mu \mathrm{g} / \mathrm{ml}$ proteinase $\mathrm{K}$ (Sigma) was added to each sample and incubated at $37^{\circ} \mathrm{C}$ overnight. The enzyme was inactivated by heating for 10 minutes at $95^{\circ} \mathrm{C}$ and samples were stored at $4^{\circ} \mathrm{C}$ until needed.

The primers consisted of a consensus primer to the framework region 3 (Fr3) of the $\mathrm{V}$ segment and two primers directed to conserved sequences from the $\mathrm{J}$ region in the immunoglobulin heavy chain gene. ${ }^{5-8}$ The sequences were as follows:

\section{Fr3: ACACGGC(C/T)(G/C)TGTATTAC TGT}

LJH: TGAGGAGACGGTGACC

VLJH: GTGACCAGGGT(N)CCTTGGCC CCAG

A semi-nested PCR method was used. ${ }^{78}$ In the first round, amplification used Fr3 and LJH primers. Two per cent of this product was used as the template for the second round of amplification, using Fr3 and VLJH primers.

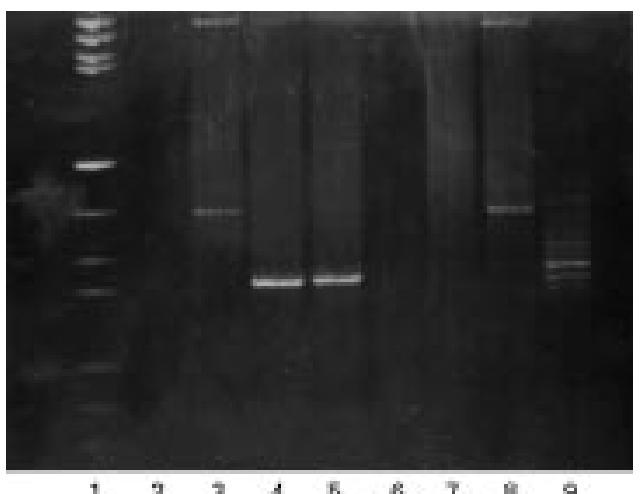

Figure 4 Ethidium bromide stained $10 \%$ polyacrylamide gel showing PCR products obtained using Fr3 primers.

Lane 1, molecular weight markers; lane 2, negative; lane 3, $B$ cell lymphoma; lanes 4 and 5, two samples from the same $B$ cell lymphoma; lane 6, negative; lane 7, tonsil; lane 8, B cell lymphoma; lane 9, reactive lymph node. Clonal bands are seen in all $B$ cell lymphoma specimens. The reactive lymph node shows a ladder and the tonsil shows a smear.
A $50 \mu 1$ reaction volume was used for each round. This consisted of $1 \times$ reaction buffer $(10 \mathrm{mM}$ Tris $\mathrm{HCl}, \mathrm{pH} 8.3,50 \mathrm{mM} \mathrm{KCl}$, $0.001 \%$ gelatin), $200 \mu \mathrm{m}$ each dNTP, $250 \mathrm{ng}$ each primer, and 0.5 units of Amplitaq (Perkin-Elmer, Warrington, Cheshire, UK). In the first round, $5 \mu \mathrm{l}$ of DNA was used with $9 \mathrm{mM} \mathrm{MgCl}{ }_{2}$. For the second round, $1 \mu \mathrm{l}$ of first round product and $3.5 \mathrm{mM} \mathrm{MgCl}{ }_{2}$ were used.

First round amplification was 30 cycles of $93^{\circ} \mathrm{C}$ for 45 seconds, $50^{\circ} \mathrm{C}$ for 45 seconds, $72^{\circ} \mathrm{C}$ for 110 seconds, then one cycle of $72^{\circ} \mathrm{C}$ for five minutes on a thermal cycler (Hybaid, Basingstoke, Hants, UK). The second round consisted of 20 cycles at the above conditions. The final products $(15 \mu \mathrm{l})$ were analysed on a $10 \%$ polyacrylamide gel (Boehringer), poststained with ethidium bromide, and viewed under UV light. A product in the 70-120 base pair (bp) range was expected.

\section{Results}

IN SITU HYBRIDISATION

The results using both sets of probes were similar, with identical results in cases selected for direct comparison. All reactive nodes showed a polyclonal pattern (fig 1), although one showed a vast excess of kappa positive cells in germinal centres. Nineteen cases $(90 \%)$ of B cell lymphoma showed light chain restriction (figs 2 and 3). A further case showed a vast excess of kappa positive cells. In one case, no signal was obtained. Tumour cells from $\mathrm{T}$ cell lymphomas were negative, with infiltrating B lymphocytes showing a polyclonal pattern.

POLYMERASE CHAIN REACTION

In 18 reactive lymph nodes and in the $T$ cell lymphomas, a ladder or a smear was seen (fig 4). Human tonsil showed a smear. In two reactive nodes, a prominent band was seen within a ladder. One of these was the case showing kappa excess on ISH. One reactive node failed to amplify. In 13 of 21 (62\%) B cell lymphomas a clonal band was detected. In seven cases, a 
ladder or smear was seen. One case failed to amplify (fig 4).

\section{Discussion}

Initially, ISH for kappa and lambda immunoglobulin light chain mRNAs was limited in sensitivity and a positive signal was seen only in lesions with a high copy message, such as multiple myeloma and plasmacytoma. ${ }^{11-13}$ The use of riboprobes increases sensitivity, ${ }^{14}{ }^{15}$ but has the disadvantage of requiring molecular biology facilities for probe production. The development of more sensitive non-isotopic techniques based on oligonucleotide cocktails labelled with digoxigenin or fluorescein, with an extended detection step, ${ }^{12}$ now permits general application to diagnostic specimens. Using this technique, we have been able to demonstrate light chain restriction in $90 \%$ of 21 cases of B cell lymphoma studied. This approximates to $95 \%$ positivity in a series of extramedullary plasmacytomas. ${ }^{3}$ In a selected series of monocytoid B cell proliferations, $100 \%$ success was reported. ${ }^{4}$ We have also found the technique useful for detecting clonal proliferations in two biopsies that had previously been labelled reactive but where, subsequently, a lymphoma has been diagnosed (unpublished data). While slight changes in intensity of signal could be achieved by altering the concentration of proteinase $\mathrm{K}$, the concentration of $10 \mu \mathrm{g} / \mathrm{ml}$ used gave the appropriate pattern of staining in all cases.

PCR techniques for the demonstration of clonality are usually based on amplification of the variable region of the immunoglobulin heavy chain using primers $\operatorname{Fr} 1,{ }^{16} \operatorname{Fr} 2,{ }^{817}$ or $\mathrm{Fr} 3^{6-8}$ of the variable sequence and to a conserved sequence of the $\mathrm{J}$ region. More recent techniques use a semi-nested PCR procedure. ${ }^{717}$ We chose to use an Fr3 primer because it is the most widely applied. Our level of detection of $62 \%$ for clonal bands in lymphoma cases is similar to some published series, ${ }^{18-20}$ but lower than that found in others, in which there was amplification in approximately $70 \%,{ }^{10}{ }^{21} 80 \%,{ }^{82}$ or $90 \%{ }^{7}$ of cases. This may be due to the high proportion of follicular and large $B$ cell lymphomas in our series (16 of 21 ), because centrocytic/centroblastic tumours have been shown to amplify less efficiently than other subtypes with Fr3 primers. ${ }^{22}{ }^{23}$ The application of a second PCR with different primers will increase the yield of positive cases, ${ }^{817} 22$ but in diagnostic practice this would increase the workload and cost for each test if applied to all diagnostic cases, and the turnaround time if applied sequentially to Fr3 negative cases. The time taken for the procedure was similar for both PCR and ISH, but the other costs of ISH were approximately half those of PCR.

On the basis of our results, we would suggest that ISH is the more useful test for general application in the diagnostic histopathology laboratory to differentiate lymphomas from reactive lymphoproliferative disorders. False negative results were rare. Both probes failed to bind in a single case, suggesting a general problem with preservation of RNA.
It is difficult to decide whether clonal bands by PCR or vast excess of one mRNA by ISH in otherwise apparently reactive lymphoid proliferations should be defined as lymphoma. ${ }^{44-26}$ In our series, we had two such cases, one identified by PCR and one by both PCR and ISH. Clinical follow up to date (three years) has not revealed a lymphoma. Such clonal proliferations have been described in orbit and conjunctiva, ${ }^{27}$ in human immunodeficiency virus related reactive lymphadenopathy, ${ }^{28}$ and frequently in salivary tissue in Sjögren's syndrome. ${ }^{28-30}$ Their biological relevance is unclear. Whether they simply represent a restricted reactive response, a benign form of lymphoma, or, drawing parallels with carcinoma, ${ }^{31} 32$ an occult malignant lymphoma of little clinical significance remains to be determined.

1 Pringle JH, Ruprai AK, Primrose L, et al. In situ hybridization of immunoglobulin light chain mRNA in paraffin sections using biotinylated or hapten-labelled oligonucleotide probes. F Pathol 1990;162:197-207.

2 Hell K, Pringle JH, Hansmann M-L, et al. Demonstration of light chain mRNA in Hodgkin's disease. F Pathol 1993;171: 137-43.

3 Aguilera NS, Kapadia SB, Nalesnik MK, et al. Extramedullary plasmacytoma of the head and neck: use of paraffin sections to assess clonality with in situ hybridization, growth factors, and the presence of Epstein-Barr virus. Mod Pathol 1995;8:503-8.

4 Plank L, Hell K, Hansmann M-L, et al. Reactive versus neoplastic monocytoid B-cell proliferations. Am f Clin Pathol 995; 103:330-7.

5 Cleary ML, Chao J, Warnke R, et al. Immunoglobulin gene rearrangement as a diagnostic criterion of B-cell lymphoma. Proc Natl Acad Sci USA 1984;81:593-7.

6 Trainor KJ, Brisco MJ, Story CJ, et al. Monoclonality in B-lymphoproliferative disorders detected at the DNA level. Blood 1990;75:2220-2.

7 Wan JH, Trainor KJ, Brisco MJ, et al. Monoclonality in B cell lymphoma detected in paraffin wax embedded sections using the polymerase chain reaction. $\mathcal{F}$ Clin Pathol 1990;43: $888-90$

8 Diss TC, Pan L, Peng H, et al. Sources of DNA for detecting B cell monoclonality using PCR. F Clin Pathol 1994;47: 493-6.

9 Inagaki $\mathrm{H}$, Nonaka $\mathrm{M}$, Nagaya $\mathrm{S}$, et al. Monoclonality in gastric lymphoma detected in formalin-fixed, paraffinembedded endoscopic biopsy specimens using immunohis-
tochemistry, in situ hybridization and polymerase chain tochemistry, in situ hybridization and
reaction. Diagn Mol Pathol 1995;4:32-8.

10 Kitamura Y, Nanba E, Inui S, et al. Diagnosis of lymphoma Kitamura Y, Nanba E, Inui S, et al. Diagnosis of lymphoma
in paraffin wax sections by nested PCR and immunohistoin paraffin wax sections by nested PCR
chemistry. $\mathcal{F}$ Clin Pathol 1996;49:333-7.

11 Akhtar N, Ruprai A, Pringle JH, et al. In situ hybridization detection of light chain mRNA in routine bone marrow trephines from patients with suspected myeloma. $\mathrm{Br} \mathcal{F ~ H a e -}$ matol 1989;73:296-301.

12 Weiss LM, Movahed LA, Chen Y-Y, et al. Detection of immunoglobulin light-chain mRNA in lymphoid tissues using a practical in situ hybridization method. Am f Pathol 1990;137:979-88.

13 Walker E, Robertson AG, Boorman JG, et al. Primary cutaneous plasmacytoma: the use of in situ hybridization to detect monoclonal immunoglobulin light chain mRNA. Histopathology 1992;20:135-8.

14 Pan L, Happerfield LC, Bobrow LG, et al. In situ detection of Ig light-chain mRNA on formalin-fixed and paraffin-
embedded tissue sections using digoxigenin-labelled RNA probes. Histochem $\mathcal{f}$ 1993;25:57-63.

15 Segal GH, Shick HE, Tubbs RR, et al. In situ hybridization analysis of lymphoproliferative disorders. Assessment of clonality by immunoglobulin light-chain messenger RNA clonality by immunoglobulin light-chain m

16 Deane M, McCarthy KP, Wiedemann LM, et al. An improved method for detection of B-lymphoid clonality by polymerase chain reaction. Br f Haematol 1990;74:251-6.

17 Ramasamy I, Brisco M, Morley A. Improved PCR method for detecting monoclonal immunoglobulin heavy chain rearrangement in B cell neoplasms. F Clin Pathol 1992;45: $770-5$.

18 Achille A, Scarpa A, Montresor M, et al. Routine application of polymerase chain reaction in the diagnosis of monoclonality of B-cell lymphoid proliferations. Diagn $\mathrm{Mo}$ Pathol 1995;4:14-24.

19 Inghirami G, Szabolcs MJ, Yee HT, et al. Detection of immunoglobulin gene rearrangement of B cell nonHodgkin's lymphomas and leukemias in fresh, unfixed and Hodgkin's lymphomas and leukemias in fresh, unfixed and
formalin-fixed paraffin-embedded tissue by polymerase
chain reaction Lab Invest 1993;68:746-57.

20 Ilyas $M$, Jalal H, Linton C, et al. The use of the polymerase chain reaction in the diagnosis of B-cell lymphomas from formalin-fixed, paraffin-embedded tissue. Histopathology 1995;26:333-8. 
21 Sukpanichnant S, Vnencak-Jones CL, McCurley TL. Determination of B-cell clonality in paraffin embedded endoscopic biopsies of abnormal lymphocytic infiltrates and gastrointestinal lymphoma by polymerase chain reaction. Am f Clin Pathol 1994;101:299-305.

22 Diss TC, Peng H, Wotherspoon AC, et al. Detection of monoclonality in low-grade B-cell lymphomas using the polymerase chain reaction is dependent on primer selection and lymphoma type. F Pathol 1993;169:291-5.

23 Ling FC, Clarke CE, Corbett WEN, et al. Sensitivity of PCR in detecting monoclonal B cell proliferations. 7 Clin Pathol 1993;46:624-7.

24 Fishleder A, Tubbs R, Hesse B, et al. Uniform detection of immunoglobulin-gene rearrangement in benign lymphoepithelial lesions. $N$ Engl f Med 1987;316:1118-21.

25 Isaacson PG, Hyjek E. Immunoglobulin-gene rearrangement in benign lymphoepithelial lesions. $N$ Engl $\mathcal{F}$ Med 1987;317:1157.

26 Weiss LM, Spagnolo DV Assessment of clonality in lymphoid proliferations. Am $\mathcal{F}$ Pathol 1993;142:1679-82.
27 Ohshima K, Kikuchi M, Sumiyoshi Y, et al. Clonality of benign lymphoid hyperplasia in orbit and conjunctiva. Path (190:436-43.

28 Dere V, Devita S, Carbone A, et al. The relevance of VDJ PCR protocols in detecting B-cell clonal expansion in lymphomas and other lymphoproliferative disorders. Tumori 1995;81:405-9.

29 Jordan RC, Pringle JH, Speight PM. High frequency of light chain restriction in labial gland biopsies of Sjogren's syndrome detected by in situ hybridization. F Pathol 1995; 177:35-40.

30 Jordan R, Diss TC, Lench NJ, et al. Immunoglobulin gene rearrangement in lymphoplasmacytic infiltrates of labial salivary gland in Sjogren's syndrome-a possible predictor of lymphoma development. Oral Surg Oral Med Oral Pathol Oral Radiol Endodontics 1995;79:723-9.

31 Lang W, Borrusch H, Vauer L. Occult carcinoma of the thyroid. Cancer 1986;58:715-19.

32 Gittes RF. Carcinoma of the prostate. $N$ Engl $7 \mathrm{Med}$ 1991;324:236-45. 